\title{
Dorothy Osborne: sensibilidad e ironía epistolar
}

\author{
VICENTE LÓPEZ FOLGADO \\ Universidad de Córdoba
}

Fecha de recepción: 15 marzo 2007

Fecha de aceptación: 29 mayo 2007

Resumen: Abordamos en este trabajo los aspectos más destacados de la personalidad de la escritora epistolar Dorothy Osborne, quien, aunque considerada 'menor' por lo parvo de su obra, sienta un claro precedente en la literatura 'realista' posterior profusa en grandes autores ya clásicos. Sterne, Smollett, Richardson o Fielding, son los iniciadores de la novela dieciochesca, basada, en gran medida, en la correspondencia epistolar entre personajes de ficción. Estas 84 cartas personales de Dorothy escritas a su amigo y prometido Sir W. Temple entre 1652 y 1654, rezuman una gran sensibilidad literaria, con un estilo personal, desenfadado y emotivo, al tiempo que una ironía ante hechos y acontecimientos sociales y políticos de su tiempo.

Palabras claves: Dorothy Osborne, cartas personales, vida cotidiana, ironía literaria, entorno cultural del siglo XVII.

Abstract: In this article we approach the major aspects of the $17^{\text {th }}$ century epistolary writer Dorothy Osborne who, though considered a minor writer for her scanty work, has been held a female forerunner of the later great $18^{\text {th }}$ century novelists. Indeed Sterne, Smollett, Richardson or Fielding, produced works that were, to a great extent, based on epistolary correspondence of fictional characters. Dorothy's 84 personal letters written to his 'friend' and would be husband Sir W. Temple between 1652 and 1654 , ooze out a great literary sensibility, through a personal, informal and emotive style, while making avail of irony in the face of various social and political facts and events of his time.

Key Words: Dorothy Osborne, personal letters, everyday life, literary irony, $17^{\text {th }}$ century cultural environment

\section{INTRODUCCIÓN}

Dorothy Osborne escribió 77 cartas a su futuro marido, William Temple, con quien compartió muy pocas horas, puesto que sus respectivas familias no aprobaban la unión de la pareja. Después de su matrimonio, debido a la ausencia de su marido, escribió aún nueve más ${ }^{1}$. Los manuscritos de las cartas editadas y publicadas por Edward Abbott Parry en

${ }^{1}$ El Corpus of Early English Correspondence (CEEC), compiladas por la University of Helsinki, comprende 84 letters de Dorothy Osborne/Temple. La edición usada aquí es la de Moore Smith en Clarendon Press, London 1928. 
1888 fueron adquiridas por el British Museum tres años más tarde, aunque otras siete permanecieron en posesión de Robert B. Longe, de Norfolk. A éste le fueron legadas en herencia por su padre, el Reverendo Robert Longe, de Suffolk ${ }^{2}$.

Según la propia narración cronológica de los hechos por parte del mismo E. Abbot Parry, a la muerte de Sir William Temple en 1699 las cartas pasaron en herencia a sus dos únicas nietas, de las cuales Elizabeth no tuvo descendencia y Dorothy se casó con un caballero residente en Suffolk, con el que tuvo un hijo que fue párroco del pueblo de Coddenham, condado de Suffolk. En los archivos de esta localidad se guardaron las cartas manuscritas, tras haber sido legadas a su sucesor en el cargo, el reverendo John Longe. Éste clérigo, que murió en 1834 fue el abuelo de Mr Robert B. Longe y padre de quien cedió los derechos de publicación a E. Abbot Parry.

Las revisión de las cartas de Dorothy Osborne de puede considerar completa a partir de la impresión de buena parte de ellas en Life of Sir William Temple escrita por el parlamentario 'tory' Thomas P. Courtenay. Sin embargo, no asumió éste en ningún momento el papel de 'editor', en el sentido convencional del término, puesto que los extractos de las cartas consignadas en el Apéndice de la antedicha obra no estaban 'editadas' esto es, debidamente ordenadas y expurgadas-, tal como el autor mismo confiesa. El propósito era, más que el de desvelar la intimidad del matrimonio, el de conocer detalles, tratándose de un destacado político, de las negociaciones relacionadas con la denominada Triple Alianza europea en una coyuntura política de crisis de la monarquía.

En efecto, Dorothy Osborne fue la esposa del mencionado Sir William Temple. Se conocieron, al parecer, en 1648 cuando Dorothy tenía 21 años y el joven William un año menos. Pero no se casarían hasta finales de 1654, teniendo que mantener, debido a la excesiva protección familiar de la joven, un noviazgo un tanto secreto. El relato de esa relación está contado unilateralmente por parte de Dorothy, puesto que el de la otra parte, según parece, ha desaparecido.

El interés de dicha correspondencia va más allá de los meros detalles personales y de otros particulares acerca de los lazos de afecto entre ambos jóvenes. En ese período incierto de interregno se debatían en el seno familiar las opiniones, posturas distintas en el plano de lo político, lo religioso y lo social. Las cartas reflejan ese estado de cosas de la sociedad de la restauración monárquica de esa mitad de siglo ${ }^{3}$.

\footnotetext{
${ }^{2}$ PARRY, Edward Abbott (ed.) The Love Letters of Dorothy Osborne. New York: Dodd, Mead and Company, 1901.

${ }^{3}$ PARKER, Kenneth (ed.) Dorothy Osborne, Letters to Sir William Temple. London: Penguin, 1987.
} 
Ambos procedían de familias de cierto 'abolengo' que habían sufrido los embates en su economía de las guerras civiles, tanto desde el lado puritano y republicano de William como desde el lado monárquico de Dorothy, hija del gobernador de Guernesey.

Dice Jonathan Wright en la reseña a la obra de Jane Dunn:

There were Osbornes-before there were Osbornes of Chicksandswho, coming out of the north, settled at Purleigh in Essex, where we find them in the year 1442. From this date, passing lightly over a hundred troubled years, we find Peter Osborne, Dorothy's greatgrandfather, born in 1521. He was Keeper of the Purse to Edward VI., and was twice married, his second wife being Alice, sister of Sir John Cheke, a family we read of in Dorothy's letters. One of his daughters, named Catharine,- - he had a well-balanced family of eleven sons and eleven daughters,- - afterwards married Sir Thomas Cheke. Peter Osborne died in 1592; and Sir John Osborne, Peter's son and Dorothy's grandfather, was the first Osborne of Chicksands ${ }^{4}$.

Sir William Temple fue aclamado como el más experto y respetado diplomático de su época debido al éxito de la Triple Alianza. También su vida familiar, a pesar de los maledicientes que nunca faltan, fue un episodio muy feliz para ambos ${ }^{5}$.

La correspondencia epistolar entre ambos no se desveló a los ojos del público hasta finales del siglo XIX. Al reseñar el historiador y ensayista decimonónico Thomas B. Macaulay ${ }^{6}$ el citado libro de Courtenay en la prestigiosa revista Edinburgh Review pergeñó una breve historia de esa relación a la luz de sus cartas. En esa semblanza este renombrado historiador cita libérrimamente esas misivas de los años 1650 que hablan por sí mismas de esa época un tanto oscura de Inglaterra.

Macaulay traza a grandes rasgos la semblanza política e histórica de los Temple, personajes notables en el devenir de Inglaterra. Del padre de

\footnotetext{
${ }^{4}$ Jane DunN, Read My Heart: Dorothy Osborne and Sir William Temple, a Love Story in the Age of Revolution. London 1938.

${ }^{5}$ Martha GUIFFARD. The Life and Character of Sir William Temple, Bart. In G.G. Moore Smith (ed.), The Early Essays and Romances of Sir William Temple, Bart. Oxford: Clarendon Press, 1930. En realidad esta breve biografía fue escrita por Lady Guiffard en 1728.

${ }^{6}$ G. O. TREVELYAN. The Life and Letters of Lord Macaulay, London: Longmans and Co., 1881 (New edition). Lord Macaulay recibió una educación esmerada, en la que los clásicos eran de rigor, en el Trinity College de Cambridge. Según su biógrafo, "he took a part in a meeting of the Anti-Slavery Society held at Freemason's Tavern on 25th of June 1824, with the Duke of Gloucester in the chair". La conocida Edinburgh Review describe su discurso como "a display of eloquence so signal for rare and matured excellence that the most practised orator may well admire how it should have come from one who then for the first time addressed a public assembly." p. 81. Hacia 1840 demuestra en Edimburgo, que lo elige como representante parlamentario, su fervor por las baladas escocesas y por su dialecto local.
} 
William, Sir Peter Temple, de interés en este artículo, nos revela lo siguiente:

Sir John Temple, like his son in after life, refused to look on politics as a game in which it was always advisable to play on the winning side, and thus we find him opposing the Duke of Ormond in Ireland in 1643, and suffering imprisonment as a partisan of the Parliament. In England, in 1648, when he was member for Chichester, he concurred with the Presbyterian vote, thereby causing the more advanced section to look askance at him, and he was turned out of the House, or secluded, to use the elegant parliamentary language of the day. From that time he lived in retirement in London until 1654, when, as we read in Dorothy's letters, he and his son go over to Ireland. He resumed his office of Master of the Rolls, and in August of that year was elected to the Irish Parliament as one of the members for Leitrim, Sligo, and Roscommon.

La vida de William fue un continuo ir y venir de la península a la isla, pues la guerra le hizo interrumpir sus estudios de dos años en Cambridge, en los que no parece que aprendió mucho. Comenta Lord Macaulay lo siguiente sobre sus cualidades literarias:

Near seven years did this arduous wooing continue. We are not accurately informed respecting Temple's movements during that time. But he seems to have led a rambling life, sometimes on the Continent, sometimes in Ireland, sometimes in London. He made himself master of the French and Spanish languages, and amused himself by writing essays and romances, an employment which at least served the purpose of forming his style. The specimen which Mr. Courtenay has preserved of these early compositions is by no means contemptible: indeed, there is one passage on Like and Dislike, which could have been produced only by a mind habituated carefully to reflect on its own operations, and which reminds us of the best things in Montaigne.

Algo más abajo afirma este excepcional historiador:

Temple appears to have kept up a very active correspondence with his mistress. His letters are lost, but hers have been preserved; and many of them appear in these volumes. Mr. Courtenay expresses some doubt whether his readers will think him justified in inserting so large a number of these epistles. We only wish that there were twice as many. Very little indeed of the diplomatic correspondence of that generation is so well worth reading.

Así pues, Sir William Temple, su marido, conservó en su poder esta serie de cartas escritas por Dorothy desde diciembre de 1652 a octubre de 1654 y no se publicó dicho manuscrito hasta finales del siglo XIX. Las cartas fueron adquiridas, como hemos comentado antes, por el British Museum en 
1891. La mejor edición de ellas la publicó G. C. Moore Smith en Clarendon Press de 1928, a pesar de lo completo y ordenado de las de Gollancz ${ }^{7}$. Lo cierto es que Dorothy Osborne atrajo poderosamente la atención de numerosos críticos victorianos. Sus cartas fueron celebradas como obras maestras del arte epistolar, tanto por el contenido que rebosa pasión e inteligencia como por su forma y estilo literario lleno de expresiones ágiles y descripciones vivaces. No le cabía la menor duda a Lord Macaulay de que se trataba de una joven "virtuous, amiable and sensible" que tenía mucho que decir sobre la relación amorosa y la condición humana. A pesar de un acusado grado de formulismo en su discurso, sin duda debido a las exigencias del género epistolar del momento, entrevemos en él ciertas actitudes de respeto y afecto personal que conquistó la estima de sus lectores decimonónicos.

La primera carta es breve y en ella abunda en expresiones notablemente formales y corteses -tal vez más notables por desconocimiento de su correspondiente- con unas pocas líneas más personales, que en cartas sucesivas se hacen más frecuentes. En la traducción hemos optado por buscar arcaísmos deliberados para dar ese efecto anacrónico al lector ${ }^{8}$.

SIR,-You may please to let my old servant (as you call him) know that I confess I owe much to his merits and the many obligations his kindness and civilities has laid upon me; but for the ten pound he claims, it is not yet due, and I think you may do well to persuade him (as a friend) to put it in the number of his desperate debts, for 'tis a very uncertain one. In all things else, pray say I am his servant. And now, sir, let me tell you that I am extremely glad (whosoever gave you the occasion) to hear from you, since (without compliment) there are very few persons in the world I am more concerned in. To find that you have overcome your long journey, that you are well and in a place where it is possible for me to see you, is such a satisfaction as I, who have not been used to many, may be allowed to doubt of. Yet I will hope my eyes do not deceive me, and that I have not forgot to read; but if you please to confirm it to me by another, you know how to direct it, for I am where I was, still the same, and always Your humble servant, D. Osborne

Ni que decir tiene, la situación de la mujer en aquella época era la de sujeción total al hombre, a quien debía obediencia y servidumbre, puesto que su papel consistía en ser elegible como esposa de un buen número de

${ }^{7}$ GolLANCZ, Israel (ed.) The Love Letters of Dorothy Osborne to Sir William Temple. London: Alexander Moring Press 1903,

8 L. VENUTI habla (The Scandals of Translation, London: Routledge, 1998) del término usado por L. Lecercle de 'remainder' que busca los efectos en el lector por formas diatópicas, diastráticas y diacrónicas que señalan diferencias relativas con respecto a la forma estándar. 
hijos. Encerrada en el hogar familiar, no le era permitido abrir una ventana hacia los asuntos que se aireaban por el mundo ${ }^{9}$. Son el estilo y el genio personal de la Osborne armas que debía emplear para desligarse de esas ataduras que la tradición secular le deparaba, pues esta situación de sujeción la percibía con claridad. En sus escritos el lector puede apreciar un fino toque de velada ironía que en ella parecía fluir con naturalidad. Las querellas e intrigas familiares tenían en su pluma un cierto tono acerbo y sutilmente crítico que no se repite en otros escritores de su tiempo.

\section{EL JUICIO DE LOS CRÍTICOS}

El Dr. Johnson, que ha entrado a saco en todos los aspectos de la literatura inglesa anterior a su siglo, también tuvo en sus manos la edición de Courtenay. En estas cartas descubre un gran valor literario y su sorpresa fue al comprobar que estaban escritas por una mujer, y de una forma privada, sin otro objetivo ni otras pretensiones literarias que los de ser leídas por una sola persona ${ }^{10}$. Su primera observación fue de carácter histórico para introducir al personaje de su marido, el destinatario de las misivas. Nos informa con sentido crítico de los estragos que la revolución puritana que la guerra trajo consigo ("The civil war disturbed even the quiet cloisters...") y las nefastas consecuencias que produjo a la educación de eminentes hombres:

William Temple, Sir John's eldest son, was born in London in the year 1628. He received his early education under his maternal uncle, was subsequently sent to school at Bishop-Stortford, and, at seventeen, began to reside at Emmanuel College, Cambridge, where the celebrated Cudworth was his tutor. The times were not favourable to study. The Civil War disturbed even the quiet cloisters and bowling-greens of Cambridge, produced violent revolutions in the government and discipline of the colleges, and unsettled the minds of the students. Temple forgot at Emmanuel all the little Greek which he had brought from Bishop-Stortford, and never retrieved the loss; a circumstance which would hardly be worth noticing but for the almost incredible fact, that fifty years later he was so absurd as to set up his own authority against that of Bentley on questions of Greek history and philology. He made no proficiency, either in the old philosophy which still lingered in the schools of Cambridge, or in the new philosophy of which Lord Bacon was the founder. But to the end of his life he

\footnotetext{
${ }^{9}$ Es interesante leer, a este respecto, el capítulo que le dedica Virginia Woolf en su obra acerca de la condición femenina: "Dorothy Osborne and her letters". The Common Reader. New York: Harcourt, Brace, 1948.

10 PARKER, Kenneth (ed.) "Dorothy Osborne: Letters to Sir William Temple, 1652-54. Observations on Love, Literature, Politics and Religion". In Early Modern Englishwoman 15001750: Contemporary Editions. Aldershot, Burlington 2002.
} 
continued to speak of the former with ignorant admiration, and of the latter with equally ignorant contempt.

Hecho el retrato intelectual del prohombre, nos ilustra Courtenay sobre las vicisitudes de su itinerario personal y la formación de su personalidad. La Universidad de Cambridge, observa K. Parker, ${ }^{11}$ apenas deja una impronta visible en su joven carácter, muy despierto, eso sí, para asuntos pragmáticos y temporales de la política belicosa de esa centuria, terreno vidrioso y complejo en el que va sin duda a sobresalir.

After residing at Cambridge two years, he departed without taking a degree, and set out upon his travels. He seems to have been then a lively, agreeable young man of fashion, not by any means deeply read, but versed in all the superficial accomplishments of a gentleman, and acceptable in all polite societies. In politics he professed himself a Royalist. His opinions on religious subjects seem to have been such as might be expected from a young man of quick parts, who had received a rambling education, who had not thought deeply, who had been disgusted by the morose austerity of the Puritans, and who, surrounded from childhood by the hubbub of conflicting sects, might easily learn to feel an impartial contempt for them all.

El encuentro de ambos ha sido motivo de no pocas especulaciones. Si creemos a Courtenay, quien recala brevemente en el encuentro en Wight, camino de Francia, del joven movilizado William con la hija de Sir Peter Osborne, por supuesto del mismo bando defensor de la monarquía. Dorothy era una joven más o menos de su edad, y el breve encuentro fortuito entre ambos prendió la mecha de una gran amistad que poco a poco encenderá el fuego de una pasión mutua alentada por las frecuentes misivas, que se intercambian de una manera casi secreta:

On his road to France, he fell in with the son and daughter of Sir Peter Osborne. Sir Peter held Guernsey for the King, and the young people were, like their father, warm for the Royal cause. At an inn where they stopped in the Isle of Wight, the brother amused himself with inscribing on the windows his opinion of the ruling powers. For this instance of malignancy the whole party were arrested and brought before the Governor. The sister, trusting to the tenderness which, even in those troubled times, scarcely any gentleman of any party ever failed to show where a woman was concerned, took the crime on herself, and was immediately set at liberty with her fellow-travellers.

${ }^{11}$ PARKER, Kenneth (ed.). Dorothy Osborne, Letters to Sir William Temple. London: Penguin, 1987. 
En la isla de Wight, camino de Francia ${ }^{12}$, se encontró con ella y su hermano, con quien tuvo ocasión de confrontar, entre otros asuntos, sus opiniones acerca de la política de entonces, ligados a cuestiones sociales en un círculo aristocrático tan esclerotizado. Ella había sido, al parecer, físicamente muy bien parecida, pero una reciente viruela había desfigurado un tanto su rostro. No obstante, Temple se convirtió en su "humilde servidor", según la fraseología de aquellos tiempos ${ }^{13}$. El cortejo prematrimonial de rigor se volvió imposible, dadas las costumbres sociales reinantes en la 'buena sociedad'. El padre del muchacho era un destacado miembro del denominado Long Parliament monárquico, y el padre de la joven era gobernador en la isla de Guernsey para el rey Charles. En una época de movilización militar, debido a la reciente revolución antimonárquica de Cromwell, sus destinos se presentaban con los tintes negros de la separación y la ausencia.

Cuando terminó la Guerra, Sir Peter volvió a su puesto inglés de Chicksands, actual condado de Bedfordshire, cercano a Londres. Allí poseían los Osborne sus tierras en las que había incluso un Priorato mixto. La familia de William tenía en perspectiva buenos lazos matrimoniales para él, al tiempo que Dorothy se vió asediada por una serie de pretendientes de prosapia, entre ellos el del crápula poco recomendable Henry Cromwell, hijo del famoso dictador puritano.

Dorothy, no obstante, se mantuvo fiel y tenaz en defensa de la maltratada personalidad de William, que fue el blanco de las críticas y puyas de sus más cercanos familiares, que se propusieron borrar de la memoria de Dorothy su recuerdo y su afecto. Ella fue constante y escribió numerosas cartas llenas de inquebrantable fe y confianza en el blanco de sus afectos.

Una muestra del comienzo de su correspondencia es su segunda carta donde ya se deja ver su enamoramiento del joven ausente. En efecto, en la segunda de sus cartas deja traslucir su añoranza, a veces de forma velada, a veces demasiado a las claras, debido a la lejanía entre ambos. En ella le escribe lo siguiente:

I writ so kindly to him the next post, and he that would not be in my debt sends me word again that you were coming over. But yours kept me from believing that and made me think you in Italy when you were in England, though I was not displeased to find myself deceived. But

\footnotetext{
${ }^{12}$ Hemos citado ya el hecho de que, debido a la Triple Alianza con Holanda y Francia para apoyar la monarquía inglesa, los hombres de armas viajaban constantemente entre estos paises europeos. Los más piensan que los partidarios del rey inglés nunca hubieran ganado a las fuerzas populares si no hubiera existido dicha Alianza, que hubiera puesto en riesgo todas las monarquias europeas, igual de despóticas y corruptas.

${ }^{13}$ CECIL, David, Two Quiet Lives: Dorothy Osborne, Thomas Gray. Indianapolis, New York: The Bobbs-Merrill Co. 1948
} 
for God sake let me ask you what you have done all this while you have been away; what you have met with in Holland that could keep you there so long; why you went no further; and why I was not to know you went so far? You may do well to satisfy me in all these. I shall so persecute you with questions else, when I see you, that you will be glad to go thither again to avoid me; though when that will be I cannot certainly say, for my father has so small a proportion of health left him since my mother's death, that I am in continual fear of him, and dare not often make use of the leave he gives me to be from home, lest he should at some time want such little services as I am able to render him. Yet I think to be in London in the next term, and am sure I shall desire it because you are there. Sir, your humble servant.

Lord Macaulay observa el entorno cultural que rezuma de las cartas de Dorothy, verdadero documento que refleja los avatares sociales, con su pertinente trasfondo político, de todo un siglo, complejo de por sí, y no por estudiado y clarificado menos contradictorio. Una de las palabras que refleja la moda de la época es la palabra "spleen", portadora de todo una semiosis modalizante, en expresión del crítico R. Hodge, de posturas sociales y psicológicas sobre el amor, el matrimonio y la familia a menudo en conflicto $^{14}$. Otro críticos, como Zinder, inciden en este trasfondo de crisis religiosa y social -en la que la economía de la nobleza está en un proceso acelerado de profundo cambio, a menudo soterrado y larvado en la poesía de esa época, y no menos en textos tales como las cartas que nos ocupana propósito de la contradictoria personalidad de John Donne. Los interesados en el pensamiento religioso y político encuentran retazos de historia viva en estos poemas y otros textos literarios escritos, como las cartas de Dorothy Osborne.

El propio Courtenay nos ilustra acerca de estos textos:

Dr. Judson Bury has kindly explained to me the meaning of the word "spleen" as the name of a disorder. "Physicians of the seventeenth century," he writes, "were well acquainted with the anatomy of the spleen, but knew very little regarding its functions. They were in the habit of ascribing many general conditions of ill-health to disturbances of the functions of the spleen, conditions which are now known to depend on disease elsewhere." There is reason to believe that

\footnotetext{
14 "Modality" es un término usado por Robert Hodge (Literature as Discourse, Polity, 1990) como el concepto clave para desentrañar lo que el escritor realmente pretendía decir. Los sistemas de modalidad del lenguaje, como sabemos por la semiótica (U. Eco, en su The Role of the Reader, 1978) se interesan por la asignación de una verdad relativa y certidumbre a los textos de ficción, y en los que se revela la actitud del escritor. Unos escritores son más opacos que otros a la hora de decidir su actitud respecto a los hechos y referentes relatados. Dice al respecto R. Hodge: "Analysis of modality takes us immediately into the dialogic context and process in which meaning was constructed, allowing us to reconstitute the poles between which it moved, its dynamic and trajectory" (1990: 158).
} 
functional disturbances of the system were then as commonly put down to "the spleen" as now-a-days they are assigned by the laity to "the liver" or "the nerves."

Cita a renglón seguido a Sir William Temple, cuyo ensayo Essay of Health and Long Life, aborda ese mismo tema no sin cierto interés, algo que ya por esa época trataba Robert Burton en su famoso e influyente ensayo Anatomy of Melancholy ${ }^{15}$ de 1655.

To what I have said in another place of the Spleen, I shall only add here, that whatever the Spleen is; whether a disease of the part so called, or of people that ail something, but they know not what: It is certainly a very ill ingredient into any other disease, and very often dangerous. For as hope is the sovereign balsam of life, and the best cordial in all distempers both of body or mind; so fear, and regret, and melancholy apprehensions, which are the usual effects of the Spleen, with the distractions, disquiets, or at least intranquillity they occasion, are the worst accidents that can attend any diseases; and make them often mortal, which would otherwise pass, and have had but a common course. I have known the most busy ministers of state, most fortunate courtiers, most vigorous youths, most beautiful virgins in the strength or flower of their age, sink under common distempers, by the force of such weights, and the cruel damps and disturbances thereby given their spirits and their blood. 'Tis no matter what is made the occasion if well improved by Spleen and melancholy apprehensions; a disappointed hope, a blot of honour, a strain of conscience, an unfortunate love, an akin jealousy, a repining grief, will serve the turn, and all alike.

Uno de los lugares fuera de casa que Dorothy visitaba con su familia eran los balnearios, lugares sociales de encuentros que proveían de cierta 'aventura' a la de por sí monótona vida encerrada en los confines de los jardines privados de una mansión. Como haría casi dos siglos más tarde Jane Austen, dando certeras pinceladas de los círculos algo más abiertos ya de la burguesía campesina, Dorothy da testimonio de esa 'gentry' nobiliaria que busca la salud en manantiales de aguas medicinales como el de Empson, en las cercanías de Londres. Este parece que era más conocido que el de Tunbridge Wells o el propio balneario de Bath. En su diario nos cuenta que va allí a 'beber las aguas' en el mes de agosto de 1652 y más adelante nos hablará del también cercano de Tunbridge Wells. Las aguas medicinales fueron un constante reclamo para la estancia a veces prolongada de la nobleza, entre la que se incluye la realeza misma, escenario propicio para encuentros más o menos 'fortuitos' con personas

${ }^{15} \mathrm{Cf}$. mi artículo "Amor y Melancolía en la poesía isabelina: comentario a la poesía de Edmund Spencer” en Cuadernos de Filología 4, Ciudad Real, 1984. 
influyentes política y socialmente que de otra manera nunca se producirían. En la tercera de sus cartas alude a la muerte de su madre y posteriormente a su vista vacacional a los balnearios, posiblemente en este caso el de Empson, el primero y más conocido, como comentamos, por entonces.

The next thing I desired to be rid on was a scurvy spleen that I had ever been subject to, and to that purpose was advised to drink the waters. There I spent the latter end of the summer, and at my coming home found that a gentleman (who has some estate in this country) had been treating with my brother, and it yet goes on fair and softly. I do not know him so well as to give you much of his character: 'tis a modest, melancholy, reserved man, whose head is so taken up with little philosophical studies, that I admire how I found a room there. 'Twas sure by chance; and unless he is pleased with that part of my humour which other people think worst, 'tis very possible the next new experiment may crowd me out again. Thus you have all my late adventures, and almost as much as this paper will hold. The rest shall be employed in telling you how sorry I am you have got such a cold. I am the more sensible of your trouble by my own, for I have newly got one myself. But I will send you that which used to cure me. 'Tis like the rest of my medicines: if it do no good, 'twill be sure to do no harm, and 'twill be no great trouble to you to eat a little on't now and then; for the taste, as it is not excellent, so 'tis not very ill.

\section{La sensibilidad literaria}

En la carta 9 cita Dorothy Osborne a Martha, la hermana de W. Temple, quien, tras enviudar muy joven, se fue a vivir con ellos toda su vida, y con ellos siempre mantuvo una afectuosa relación familiar. En su poder quedaron, como depositaria de su testamento, algunas cartas que luego usó el propio Courtenay en su edición. Cita en ella sus lecturas habituales. La mediocre obra de ficción, Cléopâtre, así como Artamanes ou Le Grand Cyrus, voluminosas obras que debió leer en el original francés, parecen haber sido los libros de cabecera por aquellas fechas. Ambas fueron obras, a pesar de su evidente mediocridad, tenidas en alta estima por entonces, tal vez para colmar el vacío existente de una obra homónima en inglés, y como preludio de la novela inglesa que iba a llegar años más tarde. Además, parece que, a pesar de existir traducciones coetáneas de esas obras, las leería en el original, sin entrar en disquisiciones sobre su preferencia o su poco aprecio por las obras traducidas. Como bien se sabe, en su educación no sólo figuraban las lenguas clásicas, sino también el aprendizaje del francés. Por entonces predominaba la idea, manifestada por Chapman, entre otros, de que en el transvase de una lengua a otra siempre se perdía inevitablemente buena parte del contenido. Ambas obras eran un buen ejemplo de la incipiente obra de ficción, aún centrada en personajes míticos, que derivaría en la novela más realista de inspiración autóctona, 
cuyos fundamentos están en la ficción epistolar. Los traductores de estos 'romances' -denominación previa a la de novela- fueron: de Le Grand Cyrus, obra cumbre de la escritora francesa Madelaine de Scudéri, conjunto de varios romances en 10 volúmenes, fue hecha ese mismo año por un tal F.G.; la traducción de la mediocre pero conocida Cléopâtre, fue realizada por Richard Loveday, escritor precisamente de cartas didácticas.

Dice Dorothy en esa carta:

You say nothing how your sister does, which makes me hope there is no more of danger in her sickness. Pray, when it may be no trouble to her, tell her how much I am her servant; and have a care of yourself this cold weather. I have read your Reine Marguerite, and will return it you when you please. If you will have my opinion of her, I think she had a good deal of wit, and a great deal of patience for a woman of so high a spirit. She speaks with too much indifference of her husband's several amours, and commends Bussy as if she were a little concerned in him. I think her a better sister than a wife, and believe she might have made a better wife to a better husband. But the story of Mademoiselle de Tournon is so sad, that when I had read it I was able to go no further, and was fain to take up something else to divert myself withal. Have you read Cléopâtre? I have six tomes on't here that I can lend you if you have not; there are some stories in't you will like, I believe. But what an ass am I to think you can be idle enough at London to read romance! No, I'll keep them till you come hither; here they may be welcome to you for want of better company. Yet, that you may not imagine we are quite out of the world here, and so be frighted from coming, I can assure you we are seldom without news, such as it is; and at this present we do abound with stories of my Lady Sunderland and Mr. Smith; with what reverence he approaches her, and how like a gracious princess she receives him, that they say 'tis worth one's going twenty miles to see it. ${ }^{16}$

Más adelante retoma ese mismo tema de las lecturas literarias, que en ese tiempo se alude a esa actividad como 'read romance', en expresión propia, cuando escribe:

I have sent you your book. And since you are at leisure to consider the moon, you may be enough to read Cléopâtre, therefore I have sent you three tomes; when you have done with these you shall have the rest, and I believe they will please. There is a story of Artemise that I will recommend to you; her disposition I like extremely, it has a great deal of practical wit; and if you meet with one Brittomart, pray send me word how you like him

\footnotetext{
${ }^{16}$ La obra a la que hace alusión, Reine Marguerite, es probablemente una traducción de Memorials of Margaret of Valois. Nótese que Dorothy leía con frecuencia obras en francés.
} 
En la carta 13 insiste una vez más sobre su lectura favorita de romances, forraje para su viva imaginación ávida de lecturas, apasionada pero enclaustrada:

I have sent you the rest of Cléopâtre, pray keep them all in your hands, and the next week I will send you a letter and directions where you shall deliver that and the books for my lady. Is it possible that she can be indifferent to anybody? Take heed of telling me such stories; if all those excellences she is rich in cannot keep warm a passion without the sunshine of her eyes, what are poor people to expect; and were it not a strange vanity in me to believe yours can be long-lived? It would be very pardonable in you to change, but, sure, in him 'tis a mark of so great inconstancy as shows him of an humour that nothing can fix.

En la carta 14 aborda un hecho político importante en su época, el golpe de estado por parte de Cromwell, que depone al Long Parliament afecto al rey y propone 'la república' puritana de la Commonwealth. Dorothy recibe estas noticias, tal vez de fuentes del propio Temple, o tal vez de los mensajeros a su propio padre en Chicksands.

But, bless me, what will become of us all now? Is not this a strange turn? What does my Lord Lisle? Sure this will at least defer your journey? Tell me what I must think on't; whether it be better or worse, or whether you are at all concern'd in't? For if you are not I am not, only if I had been so wise as to have taken hold of the offer was made me by Henry Cromwell, I might have been in a fair way of preferment, for, sure, they will be greater now than ever. Is it true that Algernon Sydney was so unwilling to leave the House, that the General was fain to take the pains to turn him out himself? Well, 'tis a pleasant world this. If Mr. Pim were alive again, I wonder what he would think of these proceedings, and whether this would appear so great a breach of the Privilege of Parliament as the demanding the 5 members? But I shall talk treason by and by if I do not look to myself. 'Tis safer talking of the orange-flower water you sent me. The carrier has given me a great charge to tell you that it came safe, and that I must do him right. As you say, 'tis not the best I have seen, nor the worst.

En la carta 18 la carta se torna íntima, misteriosa, donde expresa sus sentimientos personales en un discurso emotivo y lleno de incertidumbre sentimental.

SIR,-I have been reckoning up how many faults you lay to my charge in your last letter, and I find I am severe, unjust, unmerciful, and unkind. Oh me, how should one do to mend all these! 'Tis work for an age, and 'tis to be feared I shall be so old before I am good, that 'twill not be considerable to anybody but myself whether I am so or not. I say nothing of the pretty humour you fancied me in, in your dream, because 'twas but a dream. Sure, if it had been anything else, I should 
have remembered that my Lord L. loves to have his chamber and his bed to himself. But seriously, now, I wonder at your patience. How could you hear me talk so senselessly, though 'twere but in your sleep, and not be ready to beat me? What nice mistaken points of honour I pretended to, and yet could allow him room in the same bed with me!

Más adelante habla de lo que hace a diario, un documento muy interesante para conocer la vida cotidiana de una mujer de su status social, ciertamente privilegiado, en aquella época convulsa y de acelerados cambios:

You ask me how I pass my time here. I can give you a perfect account not only of what I do for the present, but of what I am likely to do this seven years if I stay here so long. I rise in the morning reasonably early, and before I am ready I go round the house till I am weary of that, and then into the garden till it grows too hot for me. About ten o'clock I think of making me ready, and when that's done I go into my father's chamber, from whence to dinner, where my cousin Molle and I sit in great state in a room, and at a table that would hold a great many more. After dinner we sit and talk till Mr. B. comes in question, and then I am gone. The heat of the day is spent in reading or working, and about six or seven o'clock I walk out into a common that lies hard by the house, where a great many young wenches keep sheep and cows, and sit in the shade singing of ballads. I go to them and compare their voices and beauties to some ancient shepherdesses that I have read of, and find a vast difference there; but, trust me, I think these are as innocent as those could be. I talk to them, and find they want nothing to make them the happiest people in the world but the knowledge that they are so.

\section{Intimidad e ironía}

En los quehaceres cotidianos de una mujer de entonces, confinada en los muros de una mansión rural, por extensos que fueran sus predios, figuraban el imbuirse, siguiendo las normas y horarios, de las tareas domésticas relacionadas con la vida campesina, que era la vida que tenía en su entorno. Esta agenda diaria nos parece lleno de interés para el lector que aprecia detalles de una realidad social y antropológica del pasado. Sigue Dorothy en esa misma carta describiendo sus quehaceres habituales:

Most commonly, when we are in the midst of our discourse, one looks about her, and spies her cows going into the corn, and then away they all run as if they had wings at their heels. I, that am not so nimble, stay behind; and when I see them driving home their cattle, I think 'tis time for me to return too. When I have supped, I go into the garden, and so to the side of a small river that runs by it, when I sit down and wish you were with me (you had best say this is not kind neither). In earnest, 'tis a pleasant place, and would be much more so to me if I had your 
company. I sit there sometimes till I am lost with thinking; and were it not for some cruel thoughts of the crossness of our fortunes that will not let me sleep there, I should forget that there were such a thing to be done as going to bed.

Más interesante les puede parecer a otros el que nos hable de su querido 'hermano' Thomas Peyton, en realido su cuñado (brother in law) casado con su hermana mayor y protector de Dorothy a la muerte de su padre. Pertenecía a una destacada familia nobiliaria del lugar de Knowlton, condado de Kent, y, como comisionado del rey, vivió días de prisión por imputaciones de deslealtad al nuevo régimen. Su ferviente adhesión a la corona le hizo levantarse en armas contra los sublevados en Kent y es derrotado por el propio general Fairfax. Fue hecho prisionero y condenado a la gran cárcel de la Torre de Londres. Salvada su cabeza de milagro, vuelve a los Comunes del Parlamento una vez restablecida la monarquía. Como perteneciente a una significada familia de raigambre monárquica, ella acoge también en su hogar a los familiares de ese luchador por la causa, algo que se apresura a contar a su querido William Temple, defensor asimismo de la causa política monárquica.

Since I writ this my company is increased by two, my brother Harry and a fair niece, the eldest of my brother Peyton's children. She is so much a woman that I am almost ashamed to say I am her aunt; and so pretty, that, if I had any design to gain of servants, I should not like her company; but I have none, and therefore shall endeavour to keep her here as long as I can persuade her father to spare her, for she will easily consent to it, having so much of my humour (though it be the worst thing in her) as to like a melancholy place and little company. My brother John is not come down again, nor am I certain when he will be here. He went from London into Gloucestershire to my sister who was very ill, and his youngest girl, of which he was very fond, is since dead. But I believe by that time his wife has a little recovered her sickness and loss of her child, he will be coming this way. My father is reasonably well, but keeps his chamber still, and will hardly, I am afraid, ever be so perfectly recovered as to come abroad again.

La ausencia de William hace que a veces se haga larga y dura la espera. No están ausentes los celos y desconfianzas propias de tales ausencias. El ingenio de Dorothy es tal que hace creer al ausente William, por simple chanza, que tiene otro ferviente admirador y pretendiente a su mano. Lo cual causa pavor en el enamorado William. Así lo expresa en la carta 19 hablando de un tal R. Spencer:

He has often inquired after me to hear if I were marrying, and somebody told him I had an ague, and he presently fell sick of one too, so natural a sympathy there is between us; and yet for all this, on my 
conscience, we shall never marry. He desires to know whether I am at liberty or not. What shall I tell him? Or shall I send him to you to know? I think that will be best. I'll say that you are much my friend, and that I have resolved not to dispose of myself but with your consent and approbation, and therefore he must make all his court to you; and when he can bring me a certificate under your hand, that you think him a fit husband for me, 'tis very likely I may have him. Till then I am his humble servant and your faithful friend.

La respuesta no se hizo esperar, como aparece reflejado en la siguiente carta:

SIR,- - am sorry my last letter frighted you so; 'twas no part of my intention it should; but I am more sorry to see by your first chapter that your humour is not always so good as I could wish it. 'Twas the only thing I ever desired we might differ in, and therefore I think it is denied me. Whilst I read the description on't, I could not believe but that I had writ it myself, it was so much my own.

Tampoco carece de interés la referencia al arte de esa época, como lo fue la moda del retrato en miniatura. Hace alusión Dorothy en la carta 24 a los pintores miniaturistas Samuel Cooper y John Hoskins. Se dedicaban estos pintores a realizar retratos, a menudo sólo del busto, de la nobleza y la realeza. En esta carta sabemos también sobre los ecos de los rumores sociales que el asunto amoroso de Dorothy despierta y la repercusión negativa que tiene en sus cartas.

For God's sake do not complain so that you do not see me; I believe I do not suffer less in't than you, but 'tis not to be helped. If I had a picture that were fit for you, you should have it. I have but one that's anything like, and that's a great one, but I will send it some time or other to Cooper or Hoskins, and have a little one drawn by it, if I cannot be in town to sit myself. You undo me by but dreaming how happy we might have been, when I consider how far we are from it in reality. Alas! how can you talk of defying fortune; nobody lives without it, and therefore why should you imagine you could? I know not how my brother comes to be so well informed as you say, but I am certain he knows the utmost of the injuries you have received from her. 'Tis not possible she should have used you worse than he says. We have had another debate, but much more calmly. 'Twas just upon his going up to town, and perhaps he thought it not fit to part in anger. Not to wrong him, he never said to me (whate'er he thought) a word in prejudice of you in your own person, and I never heard him accuse any but your fortune and my indiscretion. And whereas I did expect that (at least in compliment to me) he should have said we had been a couple of fools well met, he says by his troth he does not blame you, but bids me not deceive myself to think you have any great passion for me. 


\section{CONCLUSIÓN}

Puede, en principio, extrañar que hoy dediquemos estas páginas a una autora que, eclipsada por otras famosas luminarias de la poesía de ese siglo convulso y complejo, habita aún en las sombras del divino templo de las musas. No parece suscitar gran interés hoy día en el lector lo que ocurría en la literatura de ese siglo oscuro y a la vez oscurantista, si no es tal vez el estro atormentado de los poetas 'llamados metafísicos' redescubiertos hace casi cien años por T. S. Eliot, cuya inspiración religiosa era tan extraña como la de aquellos. Es precisamente lo extraño de sus preocupaciones, lo inasequible de su pensamiento y lo alejado de sus temáticas los que disuaden al incauto estudioso de cualquier acercamiento, pues su solo estudio suele provocar en el lector una buena dosis de vacío e insatisfacción.

Sin embargo, como en todo erial, de cuando en cuando brota alguna flor. Es La Osborne una de esas flores raras que merecen espigarse porque sobresalen con tonos vivos en la esterilidad de un entorno envenenado por los prejuicios religiosos y las lides político-sociales de ese siglo decimoséptimo de nuestra era, caracterizado por su cicatería artística y su raquitismo intelectual ${ }^{17}$. La cartas de la Osborne translucen una vida interior intensa, ocupada en el devenir del círculo social en torno a ella, enfrascado en actividades a menudo frívolas, y no menos ocupada en el porvenir de su pretendiente, Sir William Temple. No se conservan las cartas de éste; no obstante, desde un solo polo de la correspondencia se nos permite deducir con cierta probabilidad buena parte del contenido del otro polo.

En resumen, como observa V. Woolf en su artículo ${ }^{18}$ sobre esta extraordinaria escritora, estamos ante una mujer que, nadando contracorriente y con escasas bazas a su favor, supo expresar de forma epistolar lo que escondía su corazón y supo legarlo a las generaciones siguientes. Su gran mérito radica en que desde el seno de una familia nobiliaria y realista, lo que ya es irónico por inesperado, supo ser una luminaria en la noche oscura de los tiempos, poniendo claridad en una pequeña parcela, la de su vida particular y la de los afectos a su persona.

Una muestra de su forma de escribir se puede observar en las dos cartas cuya traducción damos a continuación. Las hemos escogido porque son indicativas de su estilo a lo largo de su obra epistolar y fiel reflejo del carácter de su relación. También destacan en ellas rasgos de una personalidad muy acusada. Su forma de razonar sin complejos ni tapujos,

${ }^{17}$ Hodge, Robert, Literature as Discourse. London: Polity Press, 1990. Merece la pena leer el capítulo dedicado por este crítico a la poesía del siglo XVII, para confirmar las sospechas del avisado lector.

${ }_{18}$ WoOLF, Virginia, "Dorothy Osborne and her letters". The Common Reader. New York: Harcourt, Brace, 1948. 
su valentía en exponer sin miedo sus aspiraciones, sin sentirse supeditada a hombre alguno -algo impensable en aquella época y en el seno de su familia conservadora a ultranza-, son hechos que contribuyen a hacer de ella una mujer excepcional, digna de ser estudiada con más profundidad que en un somero artículo que simplemente alcanza a dar breve fe de su existencia. El hecho de llamar la atención de eruditos y estudiosos, tales como Samuel Johnson, el historiador Thomas B. Macaulay o la escritora Virginia Woolf, es de por sí indicativo de su personalidad fuera de lo común. Como puede apreciar el lector, sus palabras resuenan un tanto arcaicas y extrañas, pero siempre altas y claras, incluso para oídos actuales, salvada esa distancia de trescientos cincuenta años:

And I have lived so long in the world, and so much at my own liberty, that whosoever has me must be content to take me as they find me, without hope of ever making me other than I am. I cannot so much as disguise my humour.

\section{LETTER 4}

Sir,-Not to confirm you in your belief in dreams, but to avoid your reproaches, I will tell you a pleasant one of mine. The night before I received your first letter, I dreamt one brought me a packet, and told me it was from you. I, that remembered you were by your own appointment to be in Italy at that time, asked the messenger where he had it, who told me my lady, your mother, sent him with it to me; then my memory failed me a little, for I forgot you had told me she was dead, and meant to give her many humble thanks if ever I were so happy as to see her. When I had opened the letter I found in it two rings; one was, as I remember, an emerald doublet, but broken in the carriage, I suppose, as it might well be, coming so far; t'other was plain gold, with the longest and the strangest posy that ever was; half on't was Italian, which for my life I could not guess at, though I spent much time about it; the rest was "there was a Marriage in Cana of Galilee," which, though it was Scripture, I had not that reverence for it in my sleep that I should have had, I think, if I had been awake; for in earnest the oddness on't put me into that violent laughing that I waked myself with it; and as a just punishment upon me from that hour to this I could never learn whom those rings were for, nor what was in the letter besides.

This is but as extravagant as yours, for it is as likely that your mother should send me letters as that I should make a journey to see poor people hanged, or that your teeth should drop out at this age.

And to remove the opinions you have of my niceness, or being hard to please, let me assure you I am far from desiring my husband should be fond of me at threescore, that I would not have him so at all. 'Tis true I should be 
glad to have him always kind, and know no reason why he should be wearier of being my master, than he was of being my servant. But it is very possible I may talk ignorantly of marriage; when I come to make sad experiments on it in my own person I shall know more, and say less, for fear of disheartening others (since 'tis no advantage to foreknow a misfortune that cannot be avoided), and for fear of being pitied, which of all things I hate.

Lest you should be of the same humour I will not pity you, lame as you are; and to speak truth, if you did like it, you should not have it, for you do not deserve it. Would any one in the world, but you, make such haste for a new cold before the old had left him; in a year, too, when mere colds kill as many as a plague used to do? Well, seriously, either resolve to have more care of yourself, or I renounce my friendship; and as a certain king (that my learned knight is very well acquainted with), who, seeing one of his confederates in so happy a condition as it was not likely to last, sent his ambassador presently to break off the league betwixt them, lest he should be obliged to mourn the change of his fortune if he continued his friend; But I have done, and am now at leisure to tell you that it is that daughter of my Lord of Holland (who makes, as you say, so many sore eyes with looking on her) that is here; and if I know her at all, or have any judgment, her beauty is the least of her excellences. And now I speak of her, she has given me the occasion to make a request to you; it will come very seasonably after my chiding, and I have great reason to expect you should be in the humour of doing anything for me. She says that seals are much in fashion, and by showing me some that she has, has set me a-longing for some too; such as are oldest and oddest are most prized, and if you know anybody that is lately come out of Italy, 'tis ten to one but they have a store, for they are very common there. I do remember you once sealed a letter to me with as fine a one as I have seen. It was a Neptune, I think, riding upon a dolphin; but I'm afraid it so I, with a great deal more reason, do declare that I will no longer be a friend to one that's none to himself, nor apprehend the loss of what you hazard every day at tennis. They had served you well enough if they had crammed a dozen ounces of that medicine down your throat to have made you remember a quinzy.

My old Roman head is a present for a prince. If such things come in your way, pray remember me. I am sorry my new carrier makes you rise so early, 'tis not good for your cold; how might we do that you might lie a-bed and yet I have your letter? You must use to write before he comes, I think, that it may be sure to be ready against he goes. In earnest consider on't, and take some course that your health and my letters may be both secured, for the loss of either would be very sensible to

Your humble. 
A) TRADUCCIÓN DE LA CARTA 4
Señor, - Con objeto no de reafirmaros en vuestras creencias acerca de los sueños, sino de evitar vuestros reproches, os contaré uno propio asaz placentero. La noche antes de recibir vuestra primera misiva soñé que alguien me traía un mensaje diciéndome que el remitente erais vos. Yo, que recordaba que vos debíais estar en esa época en Italia de servicio, le pregunté dónde se lo habían dado y me contestó que vuestra madre le había enviado para entregármelo. Tuve, pues, un ligero lapsus de memoria, porque vos me habíais dicho que había fallecido y deseé expresarle mi humilde agradecimiento si alguna vez me cupiera en suerte encontrármela. Cuando hube abierto la carta hallé en ella dos anillos. Uno era, creo recordar, de un doble colgante de esmeralda, que se había roto durante el transporte, como bien pudiera haber ocurrido, viniendo desde tan lejos. El otro era de oro puro con el más grande y extraño ramillete que pueda pensarse. La mitad era italiano, que nunca en la vida lo hubiera imaginado por mucho tiempo que en ello invirtiera. El resto era "se celebró una boda en Canaán de Galilea" que, aunque figuraba en las Escrituras, no lo reverenciaba como merecía en mis sueños, creo yo, tanto como despierta. Pues en verdad la rareza de ello provocó en mí tal risa que me desperté y como justo y merecido castigo no me fue nunca posible saber a quién iban destinados esos anillos, ni qué más había en la carta.

Este sueño es tan insólito como el vuestro, porque es tan verosímil que vuestra madre me enviase cartas como que yo hiciera un viaje para ver cómo colgaban a aquella pobre gente, o que se os cayeran a vos los dientes a vuestra edad. Y para borrar la opinión que vos tenéis de mi elegancia, o de ser difícil de contentar, permitidme aseguraros que estoy tan lejos de desear que mi marido sienta afecto por mí a los sesenta, que de que me vea privado totalmente de él. Es verdad que me vería asaz contenta con que siempre fuera amable y no conozco razón alguna para que se sintiera tan hastiado de ser mi amo como de ser mi siervo. Pero es posible de que esté hablando insensatamente del matrimonio. Cuando sufra tristes experiencias de él en mi propia persona llegaré a saber más, o decir menos por temor a desanimar a otros (pues no es ventaja alguna el pronosticar una desgracia que no pueda ser evitada), y por miedo a ser compadecida, algo que odio sobremanera.

Para no influir en vuestro estado de ánimo no voy a compadeceros estando cojo como estáis $y$, para ser sincera, si fue de vuestro agrado, no os voy a otorgaros tal, porque no os lo merecéis. ¿Acaso alguien en todo el orbe excepto vos se apresuraría a coger otro resfriado antes de librarse del anterior, en un año, además, en que un mero resfriado mata a más gente de lo que solía hacerlo una peste? Bueno, sinceramente, o decidís cuidaros más de vos mismo, o yo renuncio a vuestra amistad; y como cierto rey (en 
quien mi culto caballero está muy versado ${ }^{19}$ que, viendo que uno de sus aliados se mostraba en tan alegre disposición que no parecía probable que fuera a durar tal, envió raudo a su embajador para que rompiera la alianza entre ellos para no verse obligado a lamentar el cambio de su suerte si continuaba siendo su amigo. De igual modo yo, con mayor razón, declaro que no continuaré siendo amigo de alguien que no se estima en nada a sí mismo ni asume siquiera la pérdida de lo que cada día arriesga en el juego de tenis. Os han tratado asaz bien si os han obligado a engullir una docena de onzas de medicinas que os han hecho recordar padecer una amigdalitis.

Mas he concluido, y ahora me permito deciros que es la hija de mi Lord of Holland -que tanto se mortifica, como decís, mirando por ella- quien está aquí. $Y$ si la conocéis bien o si tenéis una opinión de ella, no es la belleza la mayor de las cualidades que la adornan. $Y$ ahora que la menciono, me ha brindado la ocasión para haceros una petición, que, tras mi reprimenda vendrá muy pertinente y tengo buenas razones para esperar que estéis en buena disposición de hacer algo por mí. Ella dice que los sellos están asaz de moda y, al enseñarme algunos que posee, me ha hecho desear tener algunos también. Los más valorados son los más antiguos y los más raros, y si vos conocéis a alguien que recientemente haya estado en Italia, la probabilidad es de diez a uno que guarde alguno, ya que allí son muy de uso común. Recuerdo bien que vos sellasteis una vez una carta dirigida a mí con uno tan bello como en mi vida haya visto. Era un Neptuno, creo, cabalgando sobre un delfín, pero me temo que no venía de vos, porque ya no lo he vuelto a ver.

Mi vieja cabeza romana es un regalo para un príncipe. Si por casualidad os topáis con objetos tales, recordádmelo, os lo ruego. Siento que el nuevo portador de mis misivas os haga levantaros tan temprano, lo que no es bueno para vuestro resfriado. ¿Cómo podríamos hacer para que vos permanezcáis en cama y que yo reciba vuestra misiva? Debéis escribir, creo, antes de que llegue, para que sea seguro que esté preparada antes de que él se vaya. Considerad esto seriamente y tomad una decisión que asegure ambas cosas, vuestra salud y mis cartas, porque la pérdida de ambas sería muy sentida por

Vuestra humilde servidora.

\footnotetext{
${ }^{19}$ En el libro III de Herodoto de narra la leyenda de un rey, Amasis, quien rompe la alianza con otro, Polycrates, por causa de su buena fortuna. Dorothy ha podido leer la historia en las traducciones francesas de la época (la de Saliat, del siglo anterior, o la excelente y coetánea de du Ryer).
} 


\section{LETTER 37}

SIR,-You say I abuse you; and Jane says you abuse me when you say you are not melancholy: which is to be believed? Neither, I think; for I could not have said so positively (as it seems she did) that I should not be in town till my brother came back: he was not gone when she writ, nor is not yet; and if my brother Peyton had come before his going, I had spoiled her prediction. But now it cannot be; he goes on Monday or Tuesday at farthest. I hope you did truly with me, too, in saying that you are not melancholy (though she does not believe it). I am thought so, many times, when I am not at all guilty on't. How often do I sit in company a whole day, and when they are gone am not able to give an account of six words that was said, and many times could be so much better pleased with the entertainment my own thoughts give me, that 'tis all I can do to be so civil as not to let them see they trouble me. This may be your disease. However, remember you have promised me to be careful of yourself, and that if I secure what you have entrusted me with, you will answer for the rest. Be this our bargain then; and look that you give me as good an account of one as I shall give you of t'other. In earnest, I was strangely vexed to see myself forced to disappoint you so, and felt your trouble and my own too. How often I have wished myself with you, though but for a day, for an hour: I would have given all the time I am to spend here for it with all my heart.

You could not but have laughed if you had seen me last night. My brother and Mr. Gibson were talking by the fire; and I sat by, but as no part of the company. Amongst other things (which I did not at all mind), they fell into a discourse of flying; and both agreed it was very possible to find out a way that people might fly like birds, and despatch their journeys: so I, that had not said a word all night, started up at that, and desired they would say a little more on't, for I had not marked the beginning; but instead of that, they both fell into so violent a laughing, that I should appear so much concerned in such an art; but they little knew of what use it might have been to me. Yet I saw you last night, but 'twas in a dream; and before I could say a word to you, or you to me, the disorder my joy to see you had put me into awakened me. Just now I was interrupted, too, and called away to entertain two dumb gentlemen;-you may imagine whether I was pleased to leave my writing to you for their company; - they have made such a tedious visit, too; and I am so tired with making of signs and tokens for everything I had to say. Good God! how do those that live with them always? They are brothers; and the eldest is a baronet, has a good estate, a wife and three or four children. $\mathrm{He}$ was my servant heretofore, and comes to see me still for old love's sake; but if he could have made me mistress of the world I could not have had him; and yet l'll swear he has nothing to be disliked in him but his want of tongue, which in a woman might have been a virtue. 
I sent you a part of Cyrus last week, where you will meet with one Doralise in the story of Abradah and Panthée. The whole story is very good; but the humour makes the best part of it. I am of her opinion in most things that she says in her character of "L'honnest homme" that she is in search of, and her resolution of receiving no heart that had been offered to anybody else. Pray, tell me how you like her, and what fault you find in my Lady Carlisle's letter? Methinks the hand and the style both show her a great person, and 'tis writ in the way that's now affected by all that pretend to wit and good breeding; only, I am a little scandalized to confess that she uses that word faithful,- -she that never knew how to be so in her life.

I have sent you my picture because you wished for it; but, pray, let it not presume to disturb my Lady Sunderland's. Put it in some corner where no eyes may find it out but yours, to whom it is only intended. 'Tis not a very good one, but the best I shall ever have drawn of me; for, as my Lady says, my time for pictures is past, and therefore I have always refused to part with this, because I was sure the next would be a worse. There is a beauty in youth that every one has once in their lives; and I remember my mother used to say there was never anybody (that was not deformed) but were handsome, to some reasonable degree, once between fourteen and twenty. It must hang with the light on the left hand of it; and you may keep it if you please till I bring you the original. But then I must borrow it (for 'tis no more mine, if you like it), because my brother is often bringing people into my closet where it hangs, to show them other pictures that are there; and if he miss this long thence, 'twould trouble his jealous head.

You are not the first that has told me I knew better what quality I would not have in a husband than what I would; but it was more pardonable in them. I thought you had understood better what kind of person I liked than anybody else could possibly have done, and therefore did not think it necessary to make you that description too. Those that I reckoned up were only such as I could not be persuaded to have upon no terms, though I had never seen such a person in my life as Mr. Temple: not but that all those may make very good husbands to some women; but they are so different from my humour that 'tis not possible we should ever agree; for though it might be reasonably enough expected that I should conform mine to theirs (to my shame be it spoken), I could never do it. And I have lived so long in the world, and so much at my own liberty, that whosoever has me must be content to take me as they find me, without hope of ever making me other than I am. I cannot so much as disguise my humour. When it was designed that I should have had Sir Jus., my brother used to tell he was confident that, with all his wisdom, any woman that had wit and discretion might make an ass of him, and govern him as she pleased. 
'Tis such an ease (as you say) not to be solicitous to please others: in earnest, I am no more concerned whether people think me handsome or illfavoured, whether they think I have wit or that I have none, than I am whether they think my name Elizabeth or Dorothy. I would do nobody no injury; but I should never design to please above one; and that one I must love too, or else I should think it a trouble, and consequently not do it. I have made a general confession to you; will you give me absolution? Methinks you should; for you are not much better by your own relation; therefore 'tis easiest to forgive one another. When you hear anything from your father, remember that I am his humble servant, and much concerned in his good health.

I am yours.

\section{B) TRADUCCIÓN DE LA CARTA 37}

SEÑOR, —Decís que os ofendo; y Jane dice que vos me ofendéis cuando afirmáis que no os sentís apesadumbrado. ¿a quién debo creer? A ninguno de los dos, creo; pues no podría haber afirmado tan rotundamente (como parece que ella lo hizo) que no iba a estar en la ciudad hasta que mi hermano estuviera de vuelta: no se había ido cuando ella escribió, ni de hecho se ha ido aún. Y si mi hermano Peyton hubiera venido antes de que él se hubiera marchado, habría estropeado sus predicciones. Pero ahora no puede ser; él se marcha el lunes o el martes a más tardar. Espero que vos hayáis sido también sincero conmigo cuando decíais que no sentíais tristeza, por más que ella no lo crea así. Eso pienso yo a menudo cuando no soy culpable de ello. Cuán frecuentemente me paso en compañía todo el día y, cuando se ausentan, no me siento capaz de repetir ni seis palabras de lo que se ha dicho, y muchas veces me siento tan complacida con la satisfacción que mis pensamientos me proporcionan que todo lo que yo puedo hacer por mostrarme cortés es no hacerles ver que realmente me molestan. Puede que tal sea vuestro mal. No obstante, recordad que me habéis prometido cuidar de vos mismo, y que si confío en lo que habéis participado, vos hallaréis la respuesta a lo demás. Sea, pues éste nuestro trato, y procurad darme explicaciones del primer asunto como yo os la daré del otro. Hablando en serio, sentí una abrumadora aflicción al verme obligada a desilusionaros de tal forma, y sentí vuestro pesar, así como el mío propio. Cuán a menudo he deseado estar a solas con vos, aunque fuera un solo día, una sola hora: de todo corazón daría por ello todo el tiempo que he de pasar aquí.

No podríais evitar reíros si me hubieseis visto la pasada noche. $\mathrm{Mi}$ hermano y Gibson charlaban junto al fuego y yo me sentaba muy cerca, pero aparte de su compañía. Entre otros triviales asuntos -que no eran de 
mi incumbencia- abordaron el de la posibilidad de volar. Ambos concordaron en que era posible indagar una forma de que los humanos volaran como las aves para así realizar los viajes; de modo que yo, que no había dicho ni una palabra en toda la velada, me entrometí para animarles a que siguieran hablando de ello, ya que no había prestado atención al comienzo. Pero, en vez de ello, ambos se dieron a una estentórea risa al comprobar mi interés por tal arte; pero poco sabían ellos de qué utilidad me habría servido a mí. Mas yo os contemplé ayer, pero fue en un sueño; y antes de que pudiera dirigiros una palabra o vos a mí, el extraño gozo de veros me había despertado. Justo ahora fui interrumpida, también, al llamarme para atender a dos caballeros de torpe inteligencia, —podéis imaginaros lo gustosa que dejé la pluma por su compañía; — su visita ha sido tan tediosa, además; y estoy tan harta de darles señales y signos para todo lo que tenía que decir. ¡Dios mío! ¿Qué harán los que tengan que convivir siempre con ellos? Son hermanos: el mayor es barón, tiene una buena propiedad, esposa y tres o cuatro hijos. Fue hasta hace poco servidor mío y viene a verme aún por afecto. Pero, aunque me hubiera hecho emperatriz no habría podido corresponderle. Sin embargo, juraría que nada hay de desagradable en su persona si no es la falta de conversación, que en una mujer parecera virtud.

Os envié una parte de Cyrus la semana pasada, en la que os toparéis con una tal Doralise en el relato de Abradah y Panthée. Toda la historia es muy buena, pero el humor se lleva la mejor parte. Yo estoy de acuerdo con ella en la mayoría de las cosas que dice en el personaje de "L'honnest homme" que ella persigue, y en su decisión de no aceptar un corazón que se haya ofrecido a ningún otro. Os lo ruego, decidme si os gusta ella y qué defectos encontráis en mi carta de Lady Carlisle. Paréceme que tanto la mano como el estilo revelan que es una gran persona y está escrita de una forma afecta a aquellos que aspiran al mostrar ingenio y buena educación. Sólo que me escandaliza un tanto decir que hace uso la palabra 'fiel' -ella que nunca supo serlo en toda su vida.

Os he enviado mi retrato porque lo deseabais; pero, os ruego que no penséis que va a molestar el de mi Lady Sunderlands. Ponedlo en algún rincón donde sólo vuestros ojos puedan contemplarlo, pues para ellos son. No es muy bueno, pero es el mejor que he podido dibujar de mí, puesto que, como dice mi Lady, ya se me ha pasado el momento para retratos y, por tanto, siempre he estado resistiéndome a ello, sospechando que el siguiente sería peor. En la juventud hay una belleza que todo el mundo posee una vez en su vida. Y recuerdo que mi madre solía decir que nunca existió nadie que (si no era deforme) no fuera hermoso, hasta cierto punto, alguna vez en su vida entre los catorce años y los veinte. El retrato debe estar colgado con la luz desde la izquierda, y podéis conservarlo, si así lo deseáis, hasta que os entregue el original. Pero debéis dejármelo -porque 
no es mío, si os place- porque mi hermano no deja de traer gente a mis aposentos donde está colgado para enseñarle otras pinturas que hay en ellos. Y si lo echa de menos mucho tiempo podría molestar a ese gran celoso.

No sois el primero en contarme que yo sabía muy bien qué cualidades no desearía en un esposo mejor que aquellas que desearía. Pero tal cosa era en ellos más perdonable. Pensé que vos habíais comprendido qué clase de personas me complacían mejor que ningún otro, y por ende no era menester que yo os hiciera esa descripción. Aquellos que yo identifiqué eran tales que no podrían convenirme para entablar relación alguna en absoluto, aunque no hubiera encontrado una persona en mi vida como Mr. Temple. Puede que casi todos ellos pudieran ser buenos maridos para algunas mujeres, pero tan alejados se hallan de mi manera de ser que sería imposible que nos hubiéramos puesto alguna vez de acuerdo. Pues aunque cabría esperarse sin duda que sería yo quien se amoldara a su forma de ser (muy a pesar mío, entiéndase), yo nunca podría hacer cosa tal. $Y$ ya he vivido suficientes años en este mundo, y tantos de ellos en total libertad, que quienquiera que me desposare ha de conformarse con tomarme como me hallara, sin esperanza alguna de convertirme en otra de lo que soy. No puedo en absoluto fingir mi forma de ser. Cuando se dispuso que yo debería tomar por marido a Sir Jus. ${ }^{20}$, mi hermano solía decirme que confiaba en que, a pesar de toda su sabiduría, cualquier mujer con inteligencia y discreción podría burlarse de él a placer y tener mando y autoridad sobre él.

No podría negar que posiblemente tal fuera el caso, mas eso nunca podría hacerlo, estoy segura. $\mathrm{Y}$ aunque es probable que me obligara a mi misma a cumplir cuanto fuere menester para ser una esposa con sensatez, sin embargo, más allá de eso, yo no podría nunca contemplar ningún otro plan posible. Y no podría tampoco halagarle para que pensara que le admiraba con el objeto de conseguir más de lo que él y toda su generación son merecedores.

Es tal el gusto (como vos decís) en no ser solícita en agradar a otros: hablando en serio, no me paro mientes ya más en si a la gente les parezco hermosa o poco favorecida, si les parezco inteligente o no, igual que si piensan que me llamo Elizabeth o Dorothy. A nadie causaría daño alguno.

${ }^{20}$ Se refiere a uno de sus numerosos pretendientes, el más viejo en la petición de mano de Dorothy, Sir Justinian Isham, Bart., de Lamport en Northamptonshire. Tenía unos 42 años años de edad, cuatro hijas y había enviudado en 1638. Dice Macaulay nos ilustra sobre tal pretendiente: The Rev. W. Betham, with that optimism which is characteristic of compilers of peerages, thinks "that he was esteemed one of the most accomplished persons of the time, being a gentleman, not only of fine learning, but famed for his piety and exemplary life." Dorothy thinks otherwise, and writes of him as "the vainest, impertinent, self-conceited, learned coxcomb that ever yet I saw." 
Pero nunca pretenderé agradar a más que a una persona. $Y$ a esa persona debo amarla también, si no, pensaría que es un grave obstáculo y por ende no lo haría. Os he hecho una confesión general, ¿me daréis vos la absolución? Páreceme que podríais, porque vos no sois asaz mejor merced a vuestra relación, y por ende es más fácil darnos mutuo perdón. Cuando oigáis noticias de vuestro padre recordadle que soy su humilde servidora y que me preocupa su estado de salud.

Quedo vuestra afectísima. 
Hikma 7 (2008), 109-135 